\title{
Trends and Characteristics of the Migration From Ukraine to Poland: The Aspect of Rural Areas and Conclusion for State Migration Policy ${ }^{1}$
}

\begin{abstract}
The authors describe modern global migration trends in Europe and in particular in Poland. The problems and risks for the functioning and development of rural areas of Poland during the strengthening of emigration attitudes and internal mobility of the population are identified. The aspects of the Ukrainian migration as a resource for levelling labour-deficit trends in the Polish labour market are substantiated. The official data of the Office for Foreigners in Poland, the Central Statistical Office, the Ministry of Family, Labour and Social Policy, the Department of Statistics of the National Bank of Poland, individual organisations for the study of migration between the Ukraine and Poland are presented and the growing volumes and the scale of external labour migration of Ukrainians to Poland are stated (it is shown that today there are about 1.3 million Ukrainians in Poland, which at about $3.5 \%$ of the population is a significant value); key changes in the qualitative and structural characteristics of migration are shown. The main parameters of permanent and labour migration of Ukrainians to rural areas in Poland are characterised. An important conclusion is that, despite still low volumes, there are positive trends and the structural characteristics of Ukrainian emigration to rural areas of Poland are improving. The results of the analysis of the quantitative characteristics of Ukrainian labour migration are presented in the context of their employment in types of Poland's economic activity such as agriculture,
\end{abstract}

Taras Vasyltsiv, D.Sc. (Economics), Professor, State Enterprise "Dolishniy Institute of Regional Research of NAS of Ukraine”, 4 Kozelnytska Str, 79026 Lviv, Ukraine, tgvas77@ukr.net, ORCID: 0000-0002-28896924; Ruslan Lupak, D.Sc. (Economics), Associate Professor, Lviv University of Trade and Economics, 10 Tugan-Baranovskyi Str, 79005 Lviv, Ukraine, economist_555@ukr.net, ORCID: 0000-0002-1830-1800; Olha Levytska, Ph.D. (Economics), State Enterprise "Dolishniy Institute of Regional Research of NAS of Ukraine”, 4 Kozelnytska Str, 79026 Lviv, Ukraine, o.levytska@gmail.com, ORCID: 0000-0001-81749918.

1 The research was conducted within the framework of Applied Research "Migration Activity of the Population of the Carpathian Region" (Dolishniy Institute of Regional Research of NAS of Ukraine, 2019-2021). 
forestry, fishery and hunting. The authors determine features and problematic aspects of this migration. The recommendations regarding the development of joint Ukrainian-Polish practices and regulatory and guidance provisions, as well as the priority tools of migration policy, focused on meeting the socio-economic interests of both countries, are justified.

Keywords: rural areas, state migration policy, migration of population, territorial migration system Ukraine-Poland.

\section{Introduction. General characteristics of global migration trends in Europe: challenges for rural areas of Poland}

The intensification of migration processes both in the world in general and in Europe in particular has become a specific present-day trend. As a result of objective demographic changes in the patterns of birth and death rates, partly migration, life expectancy etc., an ageing population has become a phenomenon that is specific to the European states. It is expected that in the medium term these trends will only increase, and a decrease in the number and proportion of the working-age population in the EU countries with a higher level of socio-economic development will lead to growing demand for labour, specifically in remote and rural areas. Consequently, the migration policy of these countries will be directed towards creating more favourable conditions for the migration of the labour force from other countries, primarily the EU countries. In turn, the chain reaction extends to the entire scope of the EU. In particular, in Poland the problem of replacing the vacated job opportunities has become relevant, as a result of the mass emigration of Poles after joining the EU, the increased mobility of young people, the increase in demographic risks and the increased pace of stationary and labour migration to other EU countries, including neighbouring Germany.

It should be mentioned that the process of increasing labour-deficit conditions in the Polish labour market is largely specific to its rural territories. This was to be expected considering the constant migration processes in the "village-city" structure, as well as a higher level of business location, competitive and higher paid jobs, investments, infrastructure and the potential for development and career growth in large cities compared to the rural areas.

Problems currently observed in Polish rural areas relate to continuous depopulation due to natural and migratory losses, labour outflows from agriculture (the basic sector of the rural area economy) featuring a lower level of labour productivity compared to industry, lower incomes with a poorer technical and social infrastructure (public services), poverty among the farming families etc. All these 
problems have led to growing divergence in the "village-city" economic development and a labour deficit in rural areas.

Based on the above arguments, we defined the main objectives of the research, which are as follows:

1. Identification and substantiation of the problem of poor information and analytical support for monitoring the Ukrainian migration to rural areas of Poland.

2. Analysis of available statistical data and secondary sources on migration processes between the two countries with particular attention to the aspect of rural areas in Poland and the role of Ukrainian migrants in their development.

3. Consideration of the main features and problems of labour migration from Ukraine to rural areas of Poland in terms of the age, origin and specialist structure, as well as working conditions of Ukrainian immigrants.

4. Developing proposals for improving migration policies of both states based on joint practices in regulatory and methodological provision of migration processes in rural areas in Poland.

\section{Ukrainian immigrants as a resource to level labour-deficit conditions in the Polish labour market: the aspect of rural areas}

Due to its cultural, linguistic and territorial proximity and the availability of a substantial resource of qualified labour force, Ukraine is considered one of the key countries to level imbalances and the labour-resource conditions in domestic labour markets of the EU countries and Poland in particular. The implementation of such plans is also facilitated by the unstable political and economic situation in Ukraine, exacerbated by the negative manifestations and consequences of hybrid aggression by the Russian Federation, military actions in the east of the country and ineffective and strategically unreconciled social policies that have led to deterioration in the life quality of large sections of the population.

Well-known Ukrainian scientists who have actively explored Ukrainian-Polish migration include A. Gaydutskyy, A. Gots, Y. Kurunova, E. Libanova, O. Malynovska, I. Markov, O. Pyatkovska, A. Poznyak, I. Prybytkova, N. Syrochuk, U. Sadova, M. Yaroshevych etc. The dynamics and characteristics of UkrainianPolish migrations in recent decades are presented in scientific publications by O. Malynovska (Malynovska 2013, 2015), whereas N. Syrochuk (Syrochuk 2014) has made a significant contribution to studying the factors of labour migration and forecasting the dynamics of the number of Ukrainian emigrants to the EU countries. Many researchers focus on the recent changes in migratory orientations of Ukrainian citizens after the "Revolution of Dignity" in Ukraine (Yaroshevych, Piekhal 2016), 
as well as on migration processes in terms of the military conflict in the east of the country (Gots 2018). At the same time, the problem of the intensification of the current migration processes, the low motivation for Ukrainian labour emigrants to return from abroad (including those in Poland), and the risks and consequences of significant migration flows have been considered by O. Malynovska (Malynovska 2013) and E. Libanova (Libanova 2019). Certain aspects of migration policies in Poland and Ukraine are widely disclosed in research publications by the Lviv scientific group (Dolishniy Institute of Regional Research of NAS of Ukraine 2019). Unfortunately, in Ukraine there are no comprehensive studies or statistical sources on Ukrainian emigration to rural areas in Poland, which makes this subject particularly relevant and important. Moreover, even the State Migration Service, the State Labour Service and other relevant Ukrainian government bodies do not collect such data. In this situation, it serves a major purpose to use Polish information and analytical sources on Ukrainian emigration to the rural areas of Poland.

The main institutions carrying out relevant research in Poland are the Centre for Migration Research (CMR) of the University of Warsaw and the Centre for Eastern Studies (CES). The most recent projects on Ukrainian migration issues, conducted by Polish scientists and practitioners Z. Brunarska, I. Chmelevska, M. Lesinska, V. Sivinskyy etc., consider the integration of Ukrainians, mixed marriages, the role of migrant networks in the integration processes, as well as economic structure of foreign labour resources in Poland. The dependence of the destination country's immigration policy on the structure of migration is presented in publications by P. Kachmarchyk, I. Yuzvyak and M. Piekhovska (Jóźwiak, Piechowska 2017; Kaczmarczyk et al. 2015). There have also been many reviews of Ukrainian-Polish mobility in recent years focusing on the core trends and socio-demographic structure of migrants, including a relatively limited amount of research into migration to rural areas (Brunarska et al. 2016; Lesińska 2015). Lately, several valuable studies regarding the problem of Ukrainian educational emigration to Poland (Siwiński 2017) and Ukrainian labour immigration into the Polish agriculture sector, as a basic sector of the rural area economy, have been conducted (Chmielewska, Dobroczek, Panuciak 2018; Skoczyńska-Prokopowicz 2018). The latest research by I. Chmielewska, G. Dobroczek and A. Panuciak presents the quantitative and qualitative analysis of Ukrainian labour migrants working in Poland, based on the survey conducted in the Grójec and Płońsk powiats of the Masovian voivodeship in 2017.

In general, Polish scientists have studied migration processes in much greater detail, based on numerous research and surveys, whereas for Ukrainian scientists it is mostly in the context of the overall review of migrations at a macro level. Finally, the impact of Ukrainian labour migration on the development of rural areas 
of Poland is still underestimated. This study is therefore particularly necessary to fill the gap in the literature by exploring issues of rural areas' development in Poland with due regard to Ukrainian migration.

\section{Ukrainian labour supply to the Polish labour market: the statistical evidence}

The strategic nature of the policy of encouraging Ukrainian emigration to Poland has ensured an annual increase in the number of applications filed by the Ukrainian citizens to obtain permission to stay in Poland. More than 140 thousand applications were submitted for the right of temporary stay in 2018; this was 27.4 thousand $(24.3 \%)$ more than in $2017 .{ }^{2}$ For $2013-2018$ the number of applications increased by 129.8 units (13.4 times more). It should be noted that in 2018 Ukrainian citizens additionally submitted another 9.1 and 1.4 thousand applications for permanent residence and the right to stay as long-term EU residents respectively.

Despite the high number of residence applications by Ukrainians, the corresponding positive decisions in 2018 fell slightly (Figure 1): 57.2\% (80.2 thousand applications) for temporary residence, $84.9 \%$ (7.7 thousand applications) for permanent residence and 51.1\% (718 applications) for long-term EU residency. At the same time, an active upward trend has become typical of this indicator too. The number of positive decisions on granting the Polish residency rights to Ukrainian citizens increased in 2015-2018: for a temporary stay by 42.4 thousand applications (2.1 times), for permanent residence by 983 (by 14.6\%), for a stay as a long-term EU resident by 89 (by 14.1\%).

As a result of these tendencies and due to Poland's active migration policy, the number of the Ukrainians who stay today in Poland under varying legal status is about 1.3 million (which, at about $3.5 \%$ of the population, is a significant value) (Chmielewska, Dobroczek, Panuciak 2018).

The following data also testifies to the high level, as well as the growing influence on the Polish economy of emigration from Ukraine: of the total number of foreigners who were granted temporary residency in Poland in 2018, 70.3\% were Ukrainian (whereas, for example, in 2014 it was only $40.2 \%$ ) and for work purposes it was $76.6 \%$. As of the first quarter of 2019 , Ukrainians made up $48.3 \%$ of foreigners with valid Polish residency documents (only $30.6 \%$ in 2014); in 2017, 81.7\% of work permits for foreigners were for Ukrainians (Nowiński 2019).

2 https://udsc.gov.pl/ru/statystyki/raporty-specjalne/biezaca-sytuacja-dotyczaca-ukrainy [accessed: 10.01.2019]. 


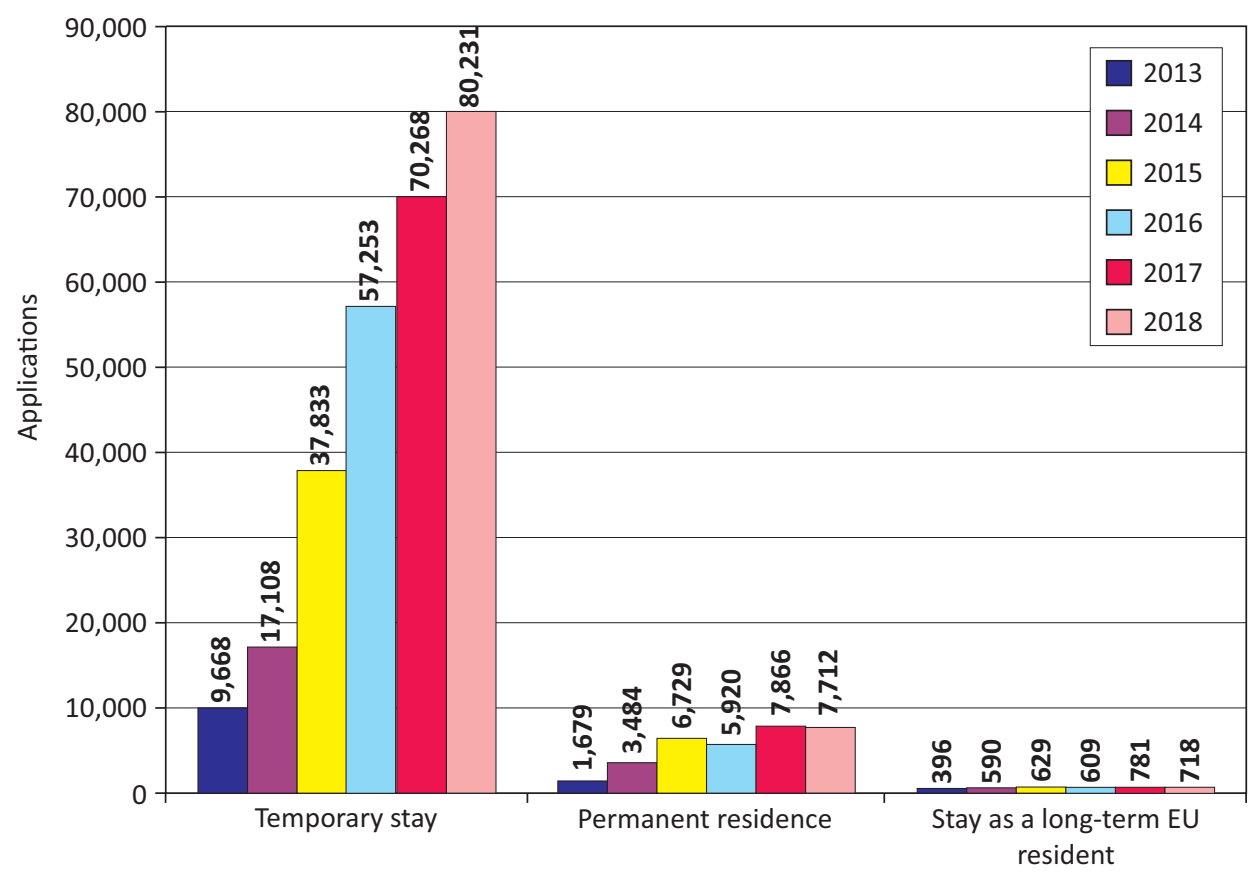

Figure 1. Number of positive decisions on granting the residence permits to citizens of Ukraine in Poland in 2013-2018

Rysunek 1. Liczba obywateli Ukrainy, w stosunku do których wydano pozytywną decyzję w sprawie zezwolenia na pobyt w Polsce, 2013-2018

Source: Urząd do Spraw Cudzoziemców. Raport na temat obywateli Ukrainy 2018. Źródło: Urząd do Spraw Cudzoziemców. Raport na temat obywateli Ukrainy 2018.

At the same time, the majority of Ukrainian immigrants are located in Warsaw and its adjacent regions (Masovian Voivodeship), as well as in the areas that specialise mainly in agriculture. Thus Ukrainian migration, in particular labour migration, has a tangible impact on the functioning of Poland's rural territories.

It should be noted that the demand by Polish employers for the employment of the Ukrainians is also growing. Thus in 2018 Polish employers filed about 1.6 million such statements, $91.0 \%$ of which were filed for Ukrainians. These values were even higher in 2017 - more than 1.8 million statements, of which 94.0\% were for Ukrainians.

For 2011-2017, both the indicators of the number and share of applications granted to Polish employers for the employment of the Ukrainians increased (Figure 2). Thus the number of work permits issued to foreigners in 2017 amounted to 235.6 thousand, while for Ukrainians it was 193.3 thousand (81.7\%). By comparison, 
the corresponding figures in 2014 amounted to 26.4 thousand and $60.3 \%$. Thus the number of work permits for Ukrainian citizens increased by 166.9 thousand (7.3 times) during 2014-2018 and their share of all work permits for foreigners rose by $21.4 \%$.

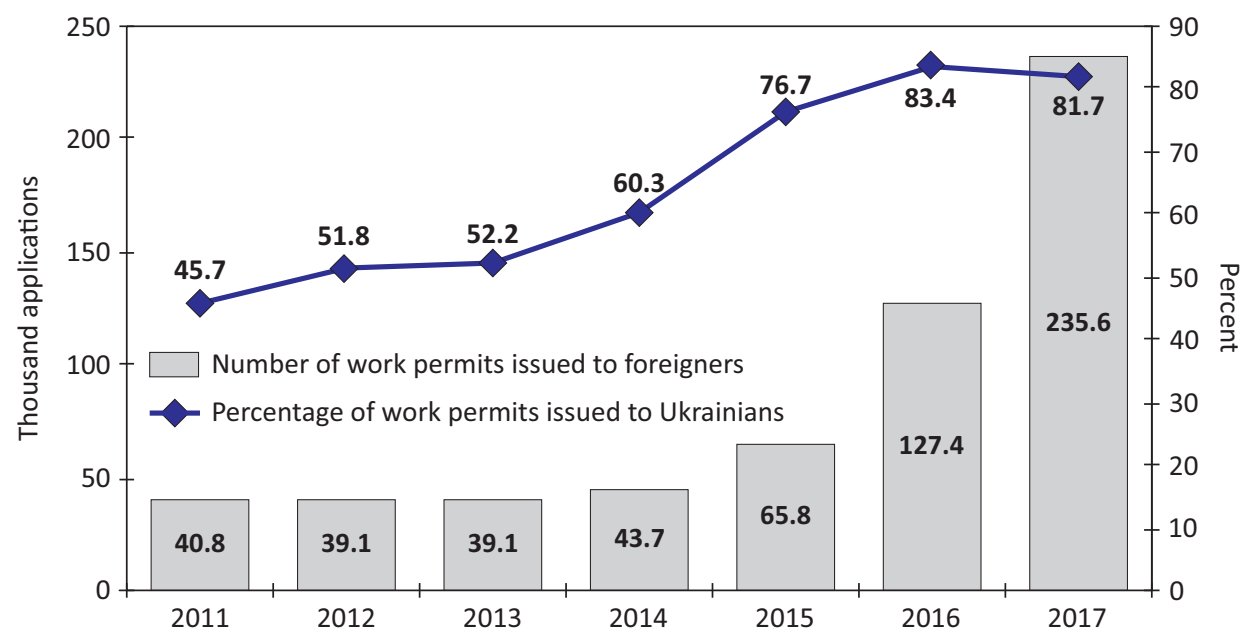

Figure 2. Distribution of long-term work permits in Poland issued to foreigners (including Ukrainian citizens) in 2011-2017

Rysunek 2. Liczba zezwoleń na pracę długoterminową dla cudzoziemców (w tym obywateli Ukrainy) w Polsce, 2011-2017

Source: Ministerstwo Rodziny, Pracy i Polityki Społecznej: Rzeczpospolita Polska 2019; Główny Urząd Statystyczny: Rzeczpospolita Polska 2019.

Źródło: Ministerstwo Rodziny, Pracy i Polityki Społecznej: Rzeczpospolita Polska 2019; Główny Urząd Statystyczny: Rzeczpospolita Polska 2019.

The overwhelming majority of Ukrainians work in Poland under what is known as the simplified procedure (according to employers' declarations or statements), which allows them to work without a work permit for six months over the following 12 months, provided that such declaration is recorded at the county labour department. At the same time, as of 2018, the greatest employment of the Ukrainians (Figure 3) was in the simplest occupations (31.8\%), operators and installers of machines and devices (22.8\%), industrial workers and craftsmen (34.5\%).

Ukrainians also work in Poland under seasonal work permits introduced in the beginning of 2018. This enables them to work for a period of not more than nine months in agriculture, gardening, tourism and other activities specified in the Regulations of the Ministry of Family, Labour and Social Policy, 8 December 
2017, in accordance with the Polish classification of activities. ${ }^{3}$ This indicates that a significant proportion of Ukrainian labour migrants work directly in the rural areas, which are an important destination for seasonal workers (Figure 4).

$\mathbf{1}$ - representatives of authorities, CEOs; $\mathbf{2}$ - specialists; $\mathbf{3}$ - technical and other mid-level staff; $\mathbf{4}$ - office workers; $\mathbf{5}$ - service providers and sellers; $\mathbf{6}$ - agricultural workers; 7 - industrial workers; 8 - operators and installers of machines and devices; 9 - the simplest occupations

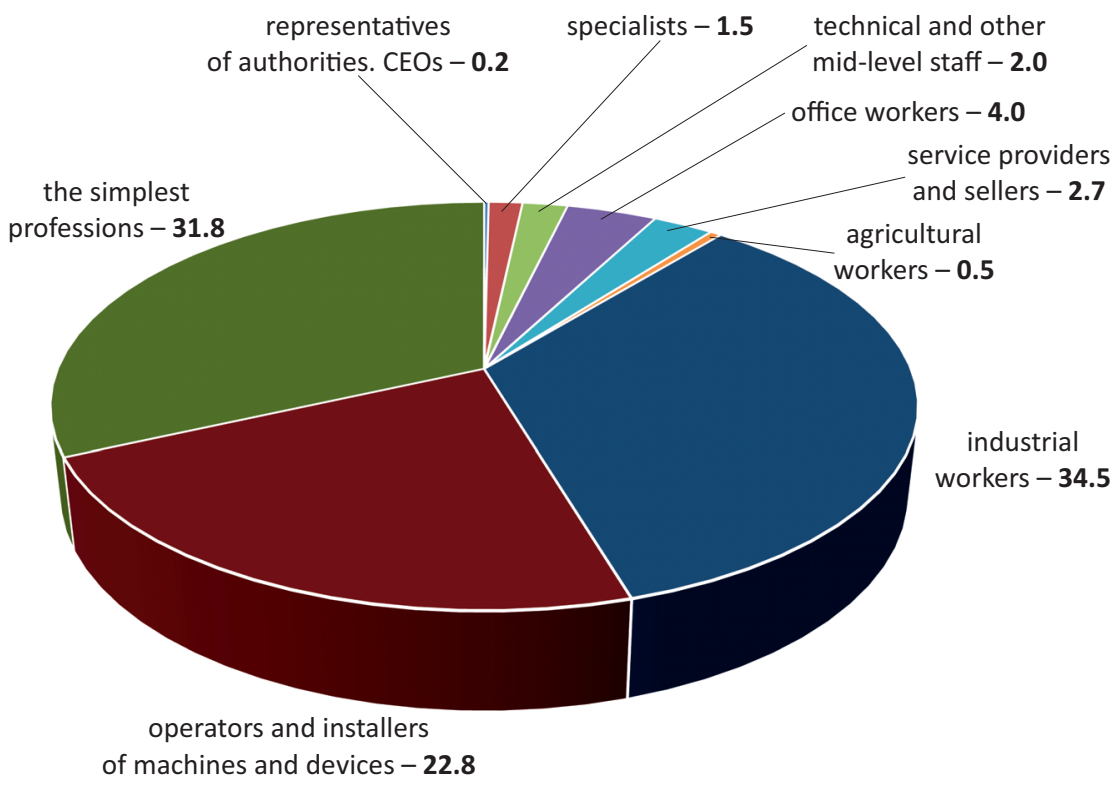

Figure 3. Employment of Ukrainian workers in Poland with work permits in 2018 by occupational and speciality classification (in \%)

Rysunek 3. Struktura zatrudnienia Ukraińców posiadających zezwolenia na pracę w Polsce (według grup zawodów i specjalizacji) w 2018 r. (w \%)

Source: Ministerstwo Rodziny, Pracy i Polityki Społecznej: Rzeczpospolita Polska 2019; Główny Urząd Statystyczny: Rzeczpospolita Polska 2019.

Źródło: Ministerstwo Rodziny, Pracy i Polityki Społecznej: Rzeczpospolita Polska 2019; Główny Urząd Statystyczny: Rzeczpospolita Polska 2019.

Thus in 2017 Polish employers submitted 303.5 thousand statements (declarations) for hiring Ukrainians in agriculture, forestry, fisheries and hunting.

3 http://prawo.sejm.gov.pl/isap.nsf/download.xsp/WDU20170002348/O/D20172348.pdf [accessed: 10.01.2019]. 
Corresponding intentions were registered in county labour departments. As we can see, there was an upward trend in applications between 2012 and 2017 (with the exception of 2016). At the same time, as a proportion of all foreigners the percentage regarding the intention to employ of Ukrainians in this type of Polish economic activity is also high $-99.0 \%$ as of 2017 (this indicator was at its highest in 2015 - at $99.4 \%)$.

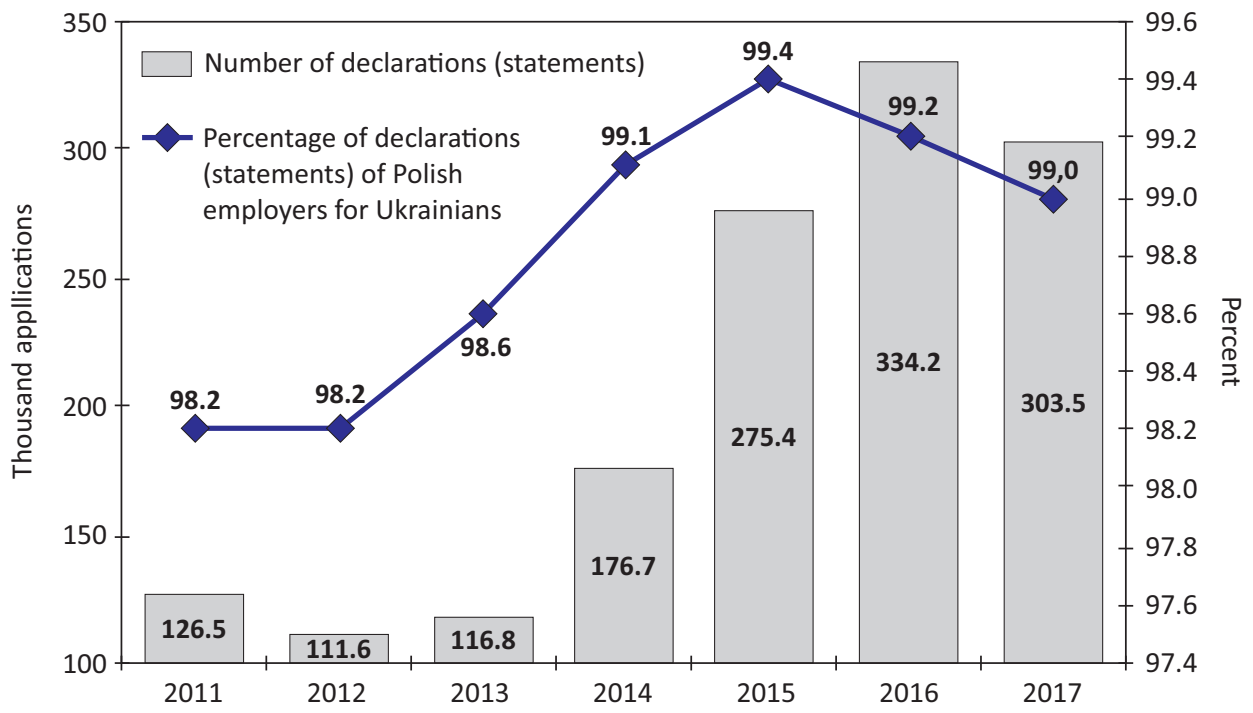

Figure 4. The number of declarations (statements) by Polish employers to employ Ukrainians in agriculture, forestry, fisheries and hunting, registered in the county departments of labour in 2011-2017

Rysunek 4. Liczba i udział oświadczeń, zarejestrowanych przez powiatowe urzędy pracy w latach 2011-2017, o zamiarze powierzenia pracy obywatelom Ukrainy w zakresie rolnictwa, leśnictwa, łowiectwa i rybactwa

Source: Ministerstwo Rodziny, Pracy i Polityki Społecznej: Rzeczpospolita Polska 2019; Główny Urząd Statystyczny: Rzeczpospolita Polska 2019.

Źródło: Ministerstwo Rodziny, Pracy i Polityki Społecznej: Rzeczpospolita Polska 2019; Główny Urząd Statystyczny: Rzeczpospolita Polska 2019.

The significant contribution by Ukrainians to the functioning of agriculture, forestry, fisheries and hunting, and hence the rural areas of Poland, is evidenced by the trend to an even more uniform distribution of permits for Ukrainians in this type of economic activity in the Polish regions. Thus, as of 2017, official permits for work in agriculture, forestry, fisheries and hunting were granted in all 


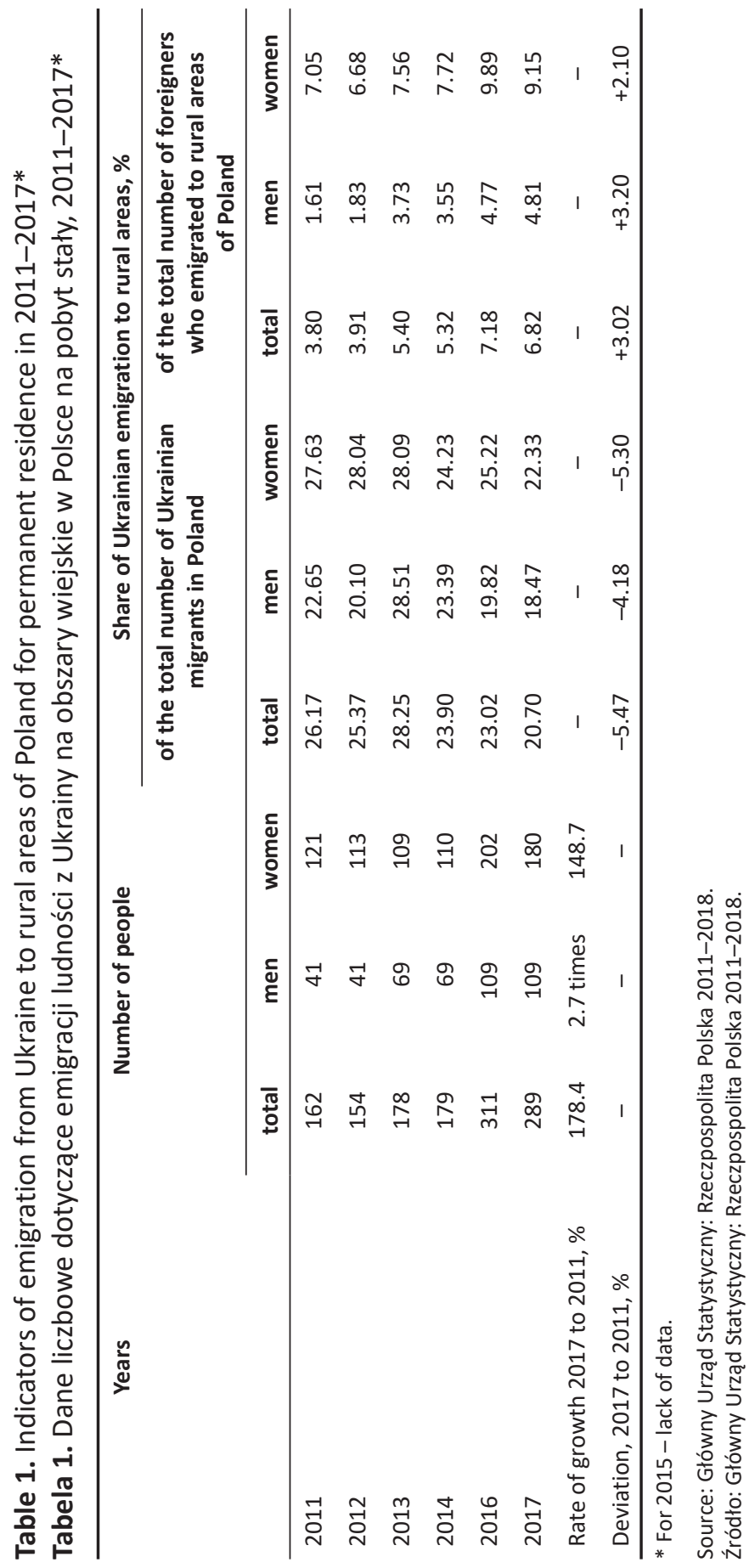


voivodeships; the largest number of permits were issued in voivodeships such as Masovia and Greater Poland; average - Lubusz, Lodz, Lublin, Silesian, West Pomeranian voivodeship.

Although the rural areas of Poland did not become the base location for labour migrants from Ukraine, their importance in the corresponding migration trends and processes remains strong and, with a more balanced, selective and effective migration policy, has the potential to grow. According to Skoczyńska-Prokopowicz (2018), a third of Ukrainians now work in Polish rural households, which makes up to 300 thousand workers out of the one million legal labour migrants from Ukraine (only half pay social contributions).

In 2017 the share of permanent emigration by Ukrainians to rural areas of Poland was $20.7 \%$, which represents an increase of 5.5 percentage points over 2011. Thus, in particular, the number of migrants from Ukraine to rural territories of Poland increased by $78.4 \%$ in 2011-2017, with women predominating (62.3\% in 2017), whereas men accounted for $37.7 \%$. Some of the most important characteristics of permanent emigration from Ukraine to Polish rural territories are given in Table 1.

Thus, despite the decrease in the proportion of Ukrainians emigrating to the rural areas of Poland, the level of Ukrainian emigration as part of the total number of foreigners who emigrate to these areas has been growing every year. In 20112017 , the figure increased by $3.02 \%$. At the same time, the share of men is growing at a higher rate $-3.2 \%$. This gives reason to argue for the increasing role and importance of migration flows from Ukraine and Poland regarding their impact on the functioning and development of the country's rural areas.

\section{Identification of the problematic aspects of the Ukrainian migration to rural areas of Poland}

According to the results of the analysis of a number of expert analytical data, there are grounds for certain conclusions regarding the features as well as problematic aspects of migration from Ukraine to rural areas of Poland (Table 2). Thus, for example, the results of the research by Chmielewska, Dobroczek, Panuciak (2018) based on the survey, carried out on farms in the Grójec and Płońsk powiats in 2017, clearly show that the employment of Ukrainians in agriculture is widespread there (with more than $70 \%$ of rural areas). At the time of the survey, $36.8 \%$ of farms employed Ukrainian citizens. Another $11.5 \%$ declared that they had employed workers from Ukraine in the past. This means that half of the farms surveyed (48.3\% in total) use or have used Ukrainian workers, and most of them are larger farms that are more active in terms of production and modernisation. 
Table 2. Features and problematic aspects of migration from Ukraine to rural areas of Poland

Tabela 2. Charakterystyka i zagadnienia problemowe migracji z Ukrainy na obszary wiejskie w Polsce

\begin{tabular}{|c|c|}
\hline Features & Problematic aspects \\
\hline $\begin{array}{l}\text { - prevailing grounds for attracting Ukrainian } \\
\text { labour migrants are the declarations } \\
\text { (statements) of the employers (95.5-96.5\%); } \\
\text { - key specialisations of labour migrants from } \\
\text { Ukraine are harvest gathering (65.0-80.0\%), } \\
\text { plant care (53.0-72.0\%), animal care (38.0- } \\
\text { 49.0\%), agricultural equipment operation } \\
\text { (23.0-24.0\%), sorting, cleaning (18.0-22.0\%); } \\
\text { - territory of origin of labour migrants are rural } \\
\text { territories of Ukraine (77.4-93.9\%); } \\
\text { - } \text { wage supplements of labour migrants from } \\
\text { Ukraine mainly provide for accommodation } \\
\text { (97.9-99.5\%), assistance in the formalities } \\
\text { (76.0-92.1\%), meals (65.2-93.6\%), transport } \\
\text { to work (51.6-84.9\%); } \\
\text { - the age structure of seasonal migrant workers } \\
\text { is fairly balanced. }\end{array}$ & $\begin{array}{l}\text { - a significant part of transactional and } \\
\text { transformational costs in accessing the Polish } \\
\text { labour market; } \\
\text { - the existence of risks associated with } \\
\text { "shadowing" of the intermediary services } \\
\text { sector when crossing the border and } \\
\text { employment registration; } \\
\text { - the existence of practices and demonstration } \\
\text { of non-standard working day and } \\
\text { employment; } \\
\text { - access only to the simplest types } \\
\text { of employment and institutional difficulties } \\
\text { of career growth; } \\
\text { - limited / lack of programmes to support } \\
\text { starting own business, the acquisition / } \\
\text { construction of housing by labour migrants } \\
\text { in rural areas of Poland; } \\
\text { - limited practice of diversified family / } \\
\text { collective employment with further group } \\
\text { adaptation of migrants to accommodation } \\
\text { and public environment in rural areas } \\
\text { of Poland. }\end{array}$ \\
\hline
\end{tabular}

Source: own study on the basis of: Chmielewska, Dobroczek, Panuciak 2018; Ilyash 2018; Wawryniuk 2017. Źródło: oprac. własne na podstawie: Chmielewska, Dobroczek, Panuciak 2018; Ilyash 2018; Wawryniuk 2017.

The occupational background of migrants, according to the survey, shows that Ukrainian employees engaged in agriculture in both powiats mainly perform simple and time-consuming tasks (e.g. harvesting and caring for plants), which do not require special qualifications. A large share of migrants are also involved in animal care, fewer in agricultural equipment operation and crop sales. However, work in the agricultural sector is characterised by very high intensity: Ukrainian employees often work 6-7 days a week, with an average 64-hour week (compared to 54 hours in the Warsaw conurbation). As for the Ukrainian immigrants themselves, they have less experience in labour migration to Poland compared to those working in urban areas. Nearly four-fifths of people surveyed had come to Poland for the first time during the two years preceding the survey. This may indicate that 
the agricultural sector is a market in which a significant proportion of new migrants take up their first job.

In terms of socio-demographic characteristics, the Ukrainian immigrants working in agriculture in the powiats studied also differ from those working in urban areas. The majority of migrants come from rural Ukraine: more often these are men of working age from small towns and villages (the average age of immigrants was about 33 and the majority were married) with a lower level of education.

It should be noted that such sample surveys significantly expand research basis of this insufficiently studied migration processes, as well as making a great contribution to the analytical support of these issues. The knowledge acquired can also be used to analyse the Polish labour market and the gaps in it -in the vast majority of cases filled by the Ukrainian migrants.

\section{Conclusions. The socio-economic interests of Ukraine and Poland: common ground within the framework of migration policy and regulation of Ukrainian migration to rural areas}

The scope of migration from Ukraine to Poland at the present stage of development of the both states is thus growing and the role of Ukrainians in Poland's socio-economic system has significantly increased. Ukraine is represented here by the largest cohort of labour migrants of all countries. The scope of both labour and permanent migration of Ukrainians to the rural areas of Poland is increasing. This is especially noticeable in the increase in the number of statements (declarations) and work permits granted for migrants in types of economic activity usually performed in rural areas, such as agriculture, forestry, fisheries and hunting.

At the same time, in most of rural areas in Poland many crucial problems remain unsolved. They are related to a low level of remuneration for Ukrainian labour migrants, inadequate protection of rights in terms of social and labour relations, hard labour and excessive working hours and the poor quality of living and recreation conditions for workers. The opportunities in relation to career growth and employment are limited, especially in leadership positions and higherskilled jobs.

In fact, the key economic interests of Ukraine and Poland in the Ukraine-Poland migration system remain unrealised, since Poland does not receive a sufficiently skilled labour force to replace the jobs of its own emigrants or to create labour prerequisites for sustainable development of its remote and rural areas. Ukraine annually loses significant amounts of its intellectual and human potential and migration trends remain virtually unmanageable, which destabilises the internal environment. 
Taking into account the circumstances of Ukrainian labour emigration to Poland revealed (in particular, to rural areas), the task of developing joint practices in regulatory and methodological provisions of migration policies of both states is being updated.

On the Polish side, the introduction of tools aimed at improving the accessibility of more prestigious occupations and higher-skilled jobs for Ukrainian workers in rural areas in Poland (not only in agriculture and related activities but also in industry, the social sphere etc.) has high potential for efficiency. Another perspective concerns the development and implementation of special programmes to support the Ukrainians in starting their own business, purchasing or building houses in rural areas of Poland, and stimulating diversified family/collective employment with the subsequent group adaptation of Ukrainian labour migrants to living in rural areas of Poland. Tackling the problem of illegal immigrants from Ukraine employed in seasonal work in rural areas is equally important.

On the Ukrainian side, the strategic priorities of the state migration policy in terms of regulation of Ukrainian emigration to rural areas in Poland should be:

- ensuring an adequate level of manageability of the Ukraine-Polish migration trends in short, medium and strategic perspectives;

- creating a system of factors stimulating the return of intellectual and human resources from rural areas in Poland to Ukraine (for example, by attracting financial resources through international programmes and cross-border cooperation programmes to create agricultural cooperatives and farms in rural areas of Ukraine);

- improving the system of support and protection of the rights of Ukrainian migrants in rural areas of Poland with the inclusion of consular and other state institutions, public organisations on migration and labour issues, intermediaries in the migration services market, Polish partners etc. Such a policy will promote faster integration of Ukrainians into the Polish environment, as well as a better realisation of the intellectual and human potential of Ukrainians in rural areas in Poland;

- developing positive joint practices and gaining the experience of effective state regulation of migration processes in rural areas, activating mutually beneficial migration exchanges in employment of the rural population of Ukraine and Poland.

In general, the current migration policies in Poland and Ukraine have no provisions governing migration to rural areas, since these processes have not been sufficiently studied. Proposals for monitoring and managing such specific migration within the Ukrainian-Polish migration system should be complemented by new 
prospective studies in both countries taking into account on the one hand the issue of national security and on the other the free movement of people.

\section{Bibliography}

Brunarska Z., Kindler M., Szulecka M., Toruńczyk-Ruiz S. (2016). Ukrainian Migration to Poland: A “Local” Mobility? In: O. Fedyuk, M. Kindler (eds.). Ukrainian Migration to the European Union Lessons from Migration Studies (pp. 115-131). Springer. https://link. springer.com/content/pdf/10.1007\%2F978-3-319-41776-9.pdf [accessed: 07.06.2019].

Chmielewska I., Dobroczek G., Panuciak A. (2018). Obywatele Ukrainy pracujaccy w Polsceraport $z$ badania. Warszawa: Departament Statystyki NBP (Narodowy Bank Polski).

Dolishniy Institute of Regional Research of NAS of Ukraine (2019). Ukrainian migration in the context of global and national challenges of the XXI century. U. Sadova (sci. ed.), O. Grynkevych, L. Semiv, R. Teslyuk, M. Bil, V. Bidak, O. Mulska, O. Ryndzak, O. Levytska, etc. Lviv.

Główny Urząd Statystyczny: Rzeczpospolita Polska (2011-2018). Rocznik Demograficzny. https://stat.gov.pl/obszary-tematyczne/roczniki-statystyczne/roczniki-statystyczne/ rocznik-demograficzny-2018,3,12.html [accessed: 20.04.2019].

Główny Urząd Statystyczny: Rzeczpospolita Polska (2019). Wiadomości Statystyczne. The Polish Statistician. https://stat.gov.pl/czasopisma/wiadomosci-statystyczne [accessed: 20.04.2019].

Gots A. (2018). International labour migration of Ukrainians in the context of a military conflict in the east of the country. Grani. 21 (3), 6-11. http://nbuv.gov.ua/UJRN/ Grani_2018_21_3_3 [accessed: 14.06.2019].

Ilyash O. (2018). European Aspirations of Ukraine in the Context of the Socio-Economic Security Risks Assessment: 2010-2018. Warsaw: Wydawnictwo Naukowe Uniwersytetu Mikołaja Kopernika.

Jaroszewicz M., Małynowska O. (2018). Najnowsza migracja z Ukrainy do Polski: (nie)stały fenomen? http://www.batory.org.pl/upload/files/Programy\%20operacyjne/ Forum\%20 Idei/Najnowsza\%20migracja\%20z\%20Ukrainy.pdf [accessed: 10.03.2019].

Jóźwiak I., Piechowska M. (2017). Crisis-driven mobility between Ukraine and Poland. What does the available data (not) tell us. CMR Working Papers, 99/157. https://www. econstor.eu/bitstream/10419/180986/1/888194552.pdf [accessed: 04.06.2019].

Kaczmarczyk P. et al. (2015). Recent trends in international migration in Poland. The 2013 SOPEMI Report. CMR Working Papers, 86/144. Centre of Migration Research, University of Warsaw, Warsaw. http://www.migracje.uw.edu.pl/publikacje/recenttrends-ininternational-migration-in-poland-the-2013-sopemi-report-2/ [accessed: 11.06.2019].

Lesińska M. (2015). Immigration of Ukrainians and Russians into Polish Inflow. Integration Trends and Policy Impacts. Migration Policy Centre. INTERACT Research Report, 6.

Libanova E. (2019). Labour migration from Ukraine: key features, drivers and impact. Economics and Sociology, 12 (1), 313-328. doi:10.14254/2071-789X.2019/12-1/19 [accessed: 03.06.2019]. 
Malynovska O. (2013). The policy of neighbouring countries with regard to compatriots as an instrument for replenishing human resources: challenges and lessons for Ukraine. Strategic Priorities, 3 (28), 138-146. http://sp.niss.gov.ua/content/articles/ files/20-1437137553.pdf [accessed: 10.06.2019].

Malynovska O. (2015). Ukrainian-Polish migration corridor: Features and importance Demography and Social Economy, 2 (24), 31-40. https://dse.org.ua/arhcive/24/2.pdf [accessed: 04.06.2019].

Ministerstwo Rodziny, Pracy i Polityki Społecznej: Rzeczpospolita Polska (2017). Rozporzadzenie w sprawie podklas działalności według Polskiej Klasyfikacji Działalności (PKD), w których wydawane sa zezwolenia na prace sezonowa cudzoziemca. http:// prawo.sejm.gov.pl/isap.nsf/download.xsp/WDU20170002348/O/D20172348.pdf [accessed: 03.06.2019].

Ministerstwo Rodziny, Pracy i Polityki Społecznej: Rzeczpospolita Polska (2019). Analizy i Raporty, https://www.gov.pl/web/rodzina/analizy-rynek-pracy [accessed: 20.04.2019].

Nowiński A. (2019). To ucina spekulacje. W końcu udało się policzyć, ilu dokładnie jest Ukraińców w Polsce. na:Temat. https://natemat.pl/266145,ilu-ukraincow-mieszka-w-polsce-nowa-metoda-liczenia-podala-dokladna-liczbe [accessed: 03.06.2019].

Siwiński W. (2017). Studenci zagraniczni w Polsce 2017. Gdzie jesteśmy? Raport Fundacji Perspektywy. http://www.studyinpoland.pl/narada2017/pdf/Otwarcie-narady-W-Siwinski.pdf [accessed: 09.06.2019].

Skoczyńska-Prokopowicz B. (2018). Foreign labour migration of Ukrainians to Poland: Statistical research from the perspective of Ukrainian studies. Zeszyty Naukowe Politechniki Śląskiej, seria: Organizacja i zarządzanie, 122, 195-204.

Syrochuk N. (2014). International labour migration of Ukrainians to the countries of the European Union: Factors of influence. Economic Bulletin of the National Technical University of Ukraine "Igor Sikorsky Kyiv Polytechnic Institute", 11, 110-118.

Urząd do Spraw Cudzoziemców. Raport na temat obywateli Ukrainy (2018). https://udsc. gov.pl/ru/statystyki/raporty-specjalne/biezaca-sytuacja-dotyczaca-ukrainy [accessed: 10.03.2019].

Wawryniuk A. (2017). Migracja Ukraińców do Polski w latach 2007-2016. Podstawy prawne, przejawy i skutki tego zjawiska. Roczniki Nauk Prawnych, 27 (3), 110-126.

Yaroshevych M., Piekhal T. (2016). Ukrainian migration to Poland after the "Revolution of Dignity": Old trends or new results? In: D. Drbokhlav, M. Yaroshevych (eds.). Ukrainian Migration During the Crisis: Forced and Labor Mobility (pp. 56-86). https://europewb.org.ua/wp-content/uploads/2016/12/Migr-mobility-ukr.pdf [accessed: 07.06.2019]. 


\section{Trendy i cechy migracji z Ukrainy do Polski - aspekt obszarów wiejskich i implikacje dla polityki migracyjnej państwa}

Streszczenie: W artykule omówiono współczesne światowe trendy migracyjne w Europie i Polsce. Zidentyfikowano zagadnienia problemowe i zagrożenia dla funkcjonowania i rozwoju obszarów wiejskich Polski na tle intensyfikacji emigracji i mobilności wewnętrznej ludności tego kraju. Uzasadniono istotę zagadnienia migracji ukraińskiej jako zasobu wyrównania sytuacji deficytu pracowników na polskim rynku pracy. Przedstawiono oficjalne dane Urzędu do Spraw Cudzoziemców w Polsce, Głównego Urzędu Statystycznego, Ministerstwa Rodziny, Pracy i Polityki Społecznej, Departamentu Statystyki Narodowego Banku Polski oraz niektórych organizacji zajmujących się badaniem migracji w ramach terytorialnego systemu migracyjnego Ukraina-Polska. Na podstawie tych danych udowodniono wzrost wielkości i zasięgu zagranicznej migracji zarobkowej Ukraińców do Polski (wykazano, że obecnie w Polsce przebywa około 1,3 mln Ukraińców, co stanowi 3,5\% ludności Polski i jest znaczącą wartością), zaprezentowano kluczowe zmiany w cechach jakościowych i strukturalnych migracji. Scharakteryzowano główne parametry migracji stałej i zarobkowej ludności z Ukrainy na obszary wiejskie w Polsce. Wyciągnięto wniosek, że pomimo wciąż niewielkiej ilości, istnieją pozytywne tendencje i poprawy struktury emigracji Ukraińców na obszary wiejskie w Polsce. Przedstawiono wyniki analizy ilościowej migracji zarobkowej Ukraińców w kontekście ich zatrudnienia w sektorze rolnictwa, leśnictwa, łowiectwa i rybactwa. Określono specyficzność i zagadnienia problemowe migracji z Ukrainy na obszary wiejskie w Polsce. Uzasadniono zalecenia dotyczące opracowania wspólnych ukraińsko-polskich praktyk oraz przepisów normatywnych i metodycznych, a także priorytetowych instrumentów polityki migracyjnej, skierowanych na zaspokojenie interesów społeczno-gospodarczych obu państw.

Słowa kluczowe: obszary wiejskie, polityka migracyjna państwa, migracja ludności, terytorialny system migracyjny Ukraina-Polska. 